\title{
Analysis of Innovative Activities Development at the Federal Universities of the Russian Federation
}

\author{
Irina B. Repina \\ Far Eastern Federal University (FEFU) \\ Vladivostok, Russia \\ repina_ira@mail.ru
}

\author{
Valeria V. Nemtsova \\ Far Eastern Federal University (FEFU) \\ Vladivostok, Russia \\ nemcovavv@mail.ru
}

\author{
Elena P. Yakimovich \\ Far Eastern Federal University (FEFU) \\ Vladivostok, Russia \\ 11021977ay@mail.ru

\section{Elena V. Kaerova} \\ Pacific State Medical University (TSMU) \\ Vladivostok, Russia \\ ekaerova@yandex.ru
}

\author{
Ekaterina A. Kozina \\ Pacific State Medical University (TSMU) \\ Vladivostok, Russia \\ ekozina.vl@gmail.com
}

\begin{abstract}
In this article, the authors present an analysis of innovative activities by the federal universities of the Russian Federation, their impact on economic development, both at the federal and the regional level. The innovations as part of the university activities are viewed as a process, where a new product, which is obtained as a result of scientific research conducted by a university, can be commoditized. Each of the universities we studied have their own competitive advantages in this or that area, which are explained by specific features of their innovative activities. However, not all of them meet the expectations of a society, mainly due to the short period of their existence. It is worth mentioning that this article explores the key areas of technical and technological innovations; nonetheless, each university also pays considerable attention to social, as well as organizational and management innovations.
\end{abstract}

Keywords - federal university, innovative activities, results of scientific and technological activities.

\section{INTRODUCTION}

At present there are ten federal universities functioning in the Russian Federation, which were established as a result of merging of the leading higher educational establishments, and evolved into the regional optimized educational clusters. These universities carry out the mission of developing a competitive human capital for the federal districts, $[1,2,3]$ which is capable to create and implement innovative products and services aimed at economic development of the country as a whole and a region (federal district) in particular $[4,5,6]$.

Organization and implementation of innovative activities by the federal universities take several stages.

Stage one involves development of legal and regulatory framework to regulate the innovative activities of the federal universities. One of the principal documents backing these activities of the federal universities is the "Strategy of Innovative Development of the Russian Federation 2020", which is based on the provisions of the "Concept of the Longterm Socioeconomic Development of the Russian Federation 2020", which, in its turn, is based on the Federal Law "On Science and State Scientific and Technical Policy". Moreover, to plan their innovative research activities, the universities should follow the guidelines outlined in the "Priority Areas for Development of Science, Technology and Engineering, and the List of Critical Technologies of the Russian Federation", as well as in the subordinate laws "On National Goals and Strategic Tasks of Development of the Russian Federation 2024", "Passport of "Science" National Project", which set forth the leading goals necessary to achieve within the frames of the country's socioeconomic development $[7,8,9]$. Since the Russian Federation consists of the federal districts, and its economy is comprised from the economy of these districts, the universities, while pursuing their activities, should be also guided by the strategic plans for their region's development.

Stage two is characterized by the activization of innovative potential of higher educational organizations, by way of their uniting into federal universities based on the region of their location. It should be noted that consolidation of universities is the worldwide trend of the recent decade $[10,11,12,13,14,15,16,17]$. The first federal universities of the Russian Federation were established in 2006: the Siberian Federal University and the Southern Federal University, which became the sites for testing the concept of educational organization of a new type.

At stage three, based on the experience of the first federal universities, the next six educational organizations of this type were established in 2010: the Baltic, Far Eastern, Kazan 
(Volga Region), Northern (Arctic), North-Eastern and Ural Federal Universities with the purpose of fulfilling strategic tasks to ensure innovative development of the relevant regional economy.

Later on, in 2012, the North Caucasian Federal University started its operation. The youngest federal university is the V.I. Vernadsky Crimean Federal University, which was launched into operation in 2014.

The aim of our research is to determine the main trends of innovative activities of the federal universities of the Russian Federation. In this context, among the tasks of our research are the following: investigation of tools for regulation of innovative activities of the federal universities of the Russian Federation; analysis of innovative activities of the federal universities; identifying the main trends of development of innovative activities of the federal universities in the Russian Federation.

This research investigates several aspects of the problem, namely, the current economic situation in the Russian Federation and areas of innovative activities of the federal universities, between which it is necessary to find out an interrelation. To achieve this goal, the convergent model was selected as the basis for our research, which makes it possible to determine the correlation between the aspects under study.

\section{DISCUSSION}

During our research, we conducted an analysis of innovative activities of the federal universities, which are most successful in this area.

Generally speaking, the innovative activities of the federal universities are developed according to the two main trends:

- participation in development programs, which are outlined in the Decree No. 218 and No. 219 of the Government of the Russian Federation;

- cooperation with the real sector enterprises and Technological platforms to create the currently perspective innovative products.

The activities of the Siberian Federal University (SibFU) are aimed at scientific support and human resourcing of the priority branches of Siberia socioeconomic development. By this moment, there are 16 small innovative enterprises functioning at the university; over 26 developments in the area of instrumentation, information and telecommunication systems and technology, fuel and energy sector, material engineering and nanotechnology, environment protection and culture, are in line with the tasks set for achievement of strategic goals of development of Siberia until 2020.

The most important developments are multipurpose regional system of Earth's remote probing; development and organization of manufacture of highly reliable electrical heating systems for non-ferrous industry; glow discharge atomic emission spectrometer; free flow micro hydropower plant.
Projects developed by SibFU have rather high export and import substitution potential, which is very important in the current economic and political situation.

The Southern Federal University (SFedU) develops its scientific innovative potential in 8 priority areas of scientific and technical development (information and communication technology and electronics, space and aviation technology, new materials and chemical technology, perspective arms, military and special equipment, living system technology, environment protection and rational nature utilization, energy saving technology), as well as in 27 critical technologies of the federal level (aircraft and rocket and space equipment, safety of nuclear power, high-performance computer systems, information and communication systems, artificial intelligence, laser and electrostatic plasma technology, materials for micro-and nanoelectronics, optical and microwave radio, polymers and composites, image recognition and analysis, element base for microelectronics, nanoelectronics and quantum computers, energy saving and others). With the participation of SFedU, 17 small innovative enterprises were established. SFedU is also a member of three clusters:

- innovative technological cluster Yuzhnoye Sozvezdie, which also includes 19 regional enterprises and organizations of Rostov Region, and which was established in fulfilment of the need for speedy implementation of innovative developments in the areas of instrumentation, radio and microelectronics, intellectual materials, marketing of innovative products, as well as targeted skills development;

- Volgodonsk industrial cluster of atomic power engineering, which key specialization is nuclear and radiation technology, and which includes 19 stakeholder organizations, companies and productions;

- Biotekhnologii (Biotechnology) cluster of 11 participants for deep grain processing in the Millerovsky District of Rostov Region, which business is aimed at organization of starch products and high-protein feeds manufacturing and deep corn processing, as well as addressing the import substitution problems.

These areas of SFedU activity are emerging due to the fact that the major problems of the Southern Federal District socioeconomic development are comparatively low labor productivity, poor innovative activities and insignificant presence of high-tech activities at the territory.

Immanuel Kant Baltic Federal University (BFU) established the science and technical park Fabrika, an advanced scientific laboratory research facility, with the purpose of creating and promoting innovative projects. Its activity helped to implement a number of large research and practice projects in perspective areas of science and technology: biotechnology, nanotechnology, neurotechnology, laser technology, robotic engineering, etc.

Eight small innovative enterprises are established on the basis of this technological park; the most important of them are Atolab, which activities are aimed at production of specialized laboratory products with nanostructured coating, and Tsentr Molekulyarnykh Technologiy (Molecular 
Engineering Center), which is engaged in creation of fluorescent dyes for marking and intracellular tracking of organelles and liposomes. Over 60 patents for inventions were obtained, most of which are related to medicine, radio engineering and electronic, materials research and analysis.

B.N. Yeltsin Ural Federal University (UrFU) has a participation interest in the capital of over 80 small innovative enterprises, which are related to two megaclusters for development of the Ural Federal District economy: fuel and energy sector and manufacturing center. In this connection, innovative activities of the university are aimed at implementing the innovative development programs together with the partner companies Rosatom, Gazprom Neft, Gazprom, Almaz-Antey, Morinsis-Agat Concern, Tactical Missiles Corporation, Roskosmos, "Electrochemical Plant" Production Association, Beloyarsk Nuclear Power Station, etc.

Main areas of research and innovative developments, which provide competitive advantages to the UrFU, are information technology and human in the information society, energy sector, resource saving technology, rational use of natural resources, nanotechnology, new materials and additive technology for energy sector, machine building and high-tech manufacturing, biotechnology for creation and study of transgenic plants, technology for creation of antivirus, antibacterial, antitumoral, immune stimulating drugs, development of chemical methods for radiopharmaceuticals synthesis, nuclear medicine technology.

Results of innovative and research activities may be commoditized with the help of seven innovation and implementation centers, which develop ties with the partner companies and get orders for applied research.

Especially perspective is the activity of the Far Eastern Federal University (FEFU): despite the competitive advantages of the Russian Far East and the Baikal Region, there are many challenges and threats, which hinder the development of their economic potential.

FEFU scientific and innovative activities are aimed at the enterprises of federal importance located in the region, such as Yu.A. Gagarin Aviation Plant, Amur Shipbuilding Plant, Sollers Automobile Company, branches of Rosneft and Transneft, Sakhalin coal and oil and gas enterprises.

Presently there are 20 small innovative enterprises and innovative technological center "Arctic" operating at the university with the aim of addressing the challenges outlined in the "Strategy of Socioeconomic Development of the Far East and Baikal Region 2025". FEFU is a member of 20 technological platforms; for two of them, namely, Aerial Mobility and Aircraft Engineering and Biotech 2030, university involvement has a practical significance. The most successfully developing areas of innovative activities are the World Ocean Resources, Energy Resources and Energy Saving Technology, Biomedicine, Russia's Cooperation with APR Countries..

\section{CONCLUSION}

Summing up, the tools regulating the innovative activities of the federal universities of the Russian Federation are Federal Law FZ-127 "On Science and National Scientific and Technical Policy", Order of the Government of the RF No. 1662-r(p) dated November 17, 2018 "Concept of the Longterm Socioeconomic Development of the Russian Federation 2020", Order of the Government of the RF No. 2227-r (p) dated December 8, 2018 "On Approval of Strategy for Innovative Development of the Russian Federation 2020", Decree of the President of the RF No. 204 dated May 7, 2018 "On National Goals and Strategic Tasks of Development of the Russian Federation 2024", "Passport of "Science" National Project", and the regional strategies of socioeconomic development.

One of the key areas of development of the innovative activities of the federal universities is establishment of small innovative enterprises. However, the number of such enterprises is still insignificant (the largest number of them is operating at $\mathrm{UrFu}$ ), which fact does not make it possible for us to believe that these enterprises can significantly impact the economy of the country or the region. However, establishment of engineering centers at the federal universities increases involvement of the best students and academic scientists into the activities of small innovative enterprises, which makes it possible to raise their efficiency.

Special role in innovative activities of the federal universities belongs to cooperation with the enterprises of federal importance located in the regions and participation in technological platforms. These measures strengthen the impact of universities on the real sector of economy of the relevant territory.

\section{References}

[1] N. A. Astashova, S. K. Bondyreva, and O. L. Zhuk "Preparation of future teachers for the implementation of the ideas of multicultural education in the interactive educational space", Education and Science vol. 21(2), 2019, pp. 27-50.

[2] R. Lostado Lorza, M. Corral Bobadilla, and F. Somovilla Gomez, "New challenges for higher education: collaboration between lecturersstudents-company", 9th International Technology, Education and Development Conference (INTED), pp. 4939-4947. Madrid, 2015.

[3] G. Richmond, M. del C. Salazar, and N. Jones, "Assessment and the Future of Teacher Education", Journal of Teacher Education, vol. 70(2), 2019, pp. 86-89.

[4] E. P. Yakimovich, V.V. Nemcova, and I. B. Repina "Aspects of financia and economic operations of Primorsky region higher education institutions", RPTSS, vol. L, pp. 878-883. Tomsk Polytechnic University, Russia, 2018.

[5] E. P. Yakimovich, I. B. Repina, and V.V. Nemcova, "Trends of Polytechnic Education Development at the Far East Federal District of the Russian Federation", Smart Technologies and Innovations in Design for Control of Technological Processes and Objects: Economy and Production, vol. 2, pp. 234-239, 2019.

[6] N. A. Goncharova, L. V. Karlova, and M. P. Zavyalova, "An Interdisciplinary Project in the Engineering Education: Obstacles in Practice and Evaluation Criteria", 27th International Business Information Management Association Conference, vol. I pp. 568. Milan, 2016.

[7] A. Sudakova, and G. Agarkov, "Global University Rankings as a Measure of Effectiveness of Higher Education Financing", 3rd International 
Multidisciplinary Scientific Conference on Social Sciences and Arts, SGEM 2016, vol. III, pp. 415-423, Albena, 2016.

[8] I. V. Abankina, L. M. Filatova, and V. A. Vynaryk, "State Policy of Higher Education Sector Financing under the Budgetary Constraints", Zhurnal Novaya Ekonomicheskaya Assotsiatsiya - Journal of The New Economic Association, vol. 3, 2016, pp. 110-143.

[9] C.I. dos Anjos, S. Silva, and C.N.Silva de Oliveira, "Policies, teacher training and pedagogical practices: reflections on inclusive childhood education", Revista Ibero-Americana de Estudos Em Educacao, vol. 14(S1), 2019, pp. 641-655.

[10] S. H. A. Zakaria, and M. A. Wahab, "Malaysian polytechnics to meet global recognition in technical and vocational education", 3rd International Conference on Education and New Learning Technologies (EDULEARN), pp. 3962-3968, Barcelona, 2011

[11] P. K. Tulsi, "Building excellence in engineering education in India", IEEE Global Engineering Education Conference (EDUCON), pp. 624629, Tallinn, 2015.

[12] J. Santos, J. Matos, and T. Araujo, "An innovative degree in mathematical engineering in the Portuguese education system submission process and evaluation", 1st International Conference of the Portuguese-Society-for-Engineering-Education (CISPEE), vol. 1, pp.259, Porto, 2013
[13] L. A. Naveira, L. A. Marcos Rodriguez Vidal Marcos, and F. J. Naveira, "Ways to adapt to higher education European area of environmental subjects in polytechnics schools. A comparison between queen's University of Belfast (Northern Ireland), Geneva University (Switzerland) and Burgos University (Spain)", 3rd International Conference on Education and New Learning Technologies (EDULEARN), pp. 2898-2901. Barcelona, 2011.

[14] F.Huang, "Higher education financing in Japan: Trends and challenges", International Journal of Educational Development, vol. 58 (I), 2018, pp. 106-115.

[15] G. Zilkha, "Innovative higher education learning outcomes and financing trends in Israel", International Journal of Educational Development, vol. 58 (I), 2018, pp. 128-136.

[16] A. Ziderman, "Financing Universities Through Vouchers: Lessons from the Republic of Georgia”. Higher Education Policy, vol. 30 (2), 2017, pp. 161-184.

[17] F. Munari, M. Sobrero, and L. Toschi, "Financing technology transfer: assessment of university-oriented proof-of-concept programmes", Technology Analysis \& Strategic Management, vol. 29 (2), 2017, pp. 233-246. 